\title{
KEMAMPUAN BERPIKIR KRITIS MATEMATIS DAN KEPERCAYAAN DIRI SISWA SMA
}

\author{
Tresnawati $^{1}$, Wahyu Hidayat ${ }^{2}$, dan Euis Eti Rohaeti ${ }^{3}$ \\ ${ }_{1,2,3}$ STKIP Siliwangi \\ ${ }^{1}$ tesnatresna123@gmail.com, ${ }^{2}$ wahyu@ stkipsiliwangi.ac.id, ${ }^{3}$ e2rht@ stkipsiliwangi.ac.id
}

\begin{abstract}
Abstrak
Penelitian ini bertujuan untuk menganalisis dan menelaah secara mendalam tentang kemampuan berpikir kritis matematis yang dipengaruhi kepercayaan diri siswa SMA. Metode dalam penelitian ini menggunakan metode korelasional dengan pendekatan kuantitatif. Populasi dalam penelitian ini adalah siswa SMA di Kota Bandung dan sampelnya sebanyak 27 orang yang ditetapkan dengan teknik purposif sampling pada salah satu SMA di Kota Bandung. Instrumen dalam penelitian ini berupa tes kemampuan berpikir kritis matematis sebanyak 6 butir soal dan skala kepercayaan diri siswa sebanyak 33 skala pernyataan. Hasil penelitian ini memperoleh kesimpulan bahwa, kemampuan berpikir kritis matematis siswa SMA dipengaruhi positif oleh kepercayaan dirinya sebesar $74,6 \%$, sedangkan 25,4\% dipengaruhi oleh faktor selain kepercayaan diri siswa.
\end{abstract}

Kata Kunci: Berpikir Kritis Matematis, Kepercayaan Diri

\begin{abstract}
This study aims to analyze and examine in depth about the students' mathematical critical thinking ability influenced by self-confidence. The study was designed in the form of experiments using correlational method with quantitative approach. The population in this research is high school students in Bandung and the sample as many as 27 people determined by purposive sampling technique in one of high school in Bandung. The instrument in this research is the test of mathematical critical thinking ability as much as 6 items and the scale of students' selfconfidence as much as 33 scale statement. Based on the results and discussion, it is concluded that the students' mathematical critical thinking ability influenced positively by self-confidence equal to $74.6 \%$, while $25.4 \%$ influenced by factors other than student self-confidence.
\end{abstract}

Kata Kunci: Mathematical Critical Thinking, Self-Confidence

\section{PENDAHULUAN}

Kemampuan berpikir kritis merupakan salah satu kemampuan berpikir yang penting untuk dimiliki oleh peserta didik. Hal itu dikarenakan bahwa berpikir kritis merupakan sebuah proses yang bermuara pada penarikan kesimpulan tentang apa yang harus kita percayai dan tindakan apa yang akan kita lakukan (Rohaeti, 2010; Sumarmo, Hidayat, Zukarnaen, Hamidah, \& Sariningsih, 2012).

Fakta di lapangan menunjukkan bahwa kemampuan berpikir kritis masih cenderung rendah. hal ini dikarenakan siswa masih cenderung belum berhasil menjawab dengan benar dari permasalahan soal-soal non rutin yang diberikan. Selain itu siswa juga sering mengalami kesulitan dalam menyelesaikan masalah yang menuntut siswa harus berpikir kritis, dikarenakan siswa jarang dilatih bagaimana menyelesaikan soal yang memerlukan kemampuan berpikir kritis. Berdasarkan hal tersebut, jelaslah bahwa siswa dalam mengerjakan soal-soal berpikir kritis matematis masih mengalami terdapat kesulitan terhadap beberapa indikator dalam menganalisis suatu pertanyaan, jawaban, argumen yang relevan dan memeriksa kembali suatu pernyataan atau proses yang bisa dikatakan masih belum bisa membuktikan hasil yang benar atau salah (Fatmawati, Mardiyana, \& Triyanto, 2014; Noordyana, 2016). 
Dalam mengembangkan kemampuan matematika khususnya kemampuan berpikir kritis, seorang peserta didik harus memiliki sikap yakin dan percaya akan kemampuan sendiri sehingga terhindar dari rasa cemas dan ragu. Sikap tersebut dapat diartikan sebagai daya juang seseorang dalam memecahkan permasalahan yang sedang dihadapi(Hidayat, 2017; Rosita, 2017).

Salah satu sikap dalam memecahkan permasalahannya tersebut yaitu kepercayaan diri. Kepercayaan diri yang dimiliki setiap individu dalam memandang dirinya dengan mengacu pada konsep diri. Selain itu kepercayaan diri juga akan memberikan motivasi terhadap pencapaian keberhasilan seseorang dalam memecahkan permasalahan yang sedang dihadapi. Sehingga semakin tinggi kepercayaan seseorang terhadap kemampuan diri sendiri, semakin kuat pula semangat untuk menyelesaikan pekerjaannya (Hendriana, 2014).

Berdasarkan hal tersebut, perlu dilakukan penelitian yang menjadi urgensi dari permasalahan tentang seberapa besar kemampuan berpikir kritis matematis dipengaruhi oleh kepercayaan diri siswa.

\section{METODE PENELITIAN}

Metode dalam penelitian ini menggunakan metode korelasional dengan pendekatan kuantitatif yang bertujuan untuk mengetahui dengan menganalisis dan menelaah secara mendalam tentang kemampuan berpikir kritis matematis yang dipengaruhi kepercayaan diri siswa SMA. Populasi dalam penelitian ini adalah siswa SMA di Kota Bandung. Sedangkan sampelnya sebanyak 27 orang yang ditetapkan secara purposif pada salah satu SMA di Kota Bandung. Instrument dalam penelitian ini menggunakan tes dan non tes. Instrument tes tersebut didasarkan pada penilaian karakteristik yang baik terhadap kemampuan berpikir kritis matematis, sedangkan instrument non tes didasarkan pada penilaian karakteristik yang baik terhadap kepercayaan diri siswa. Tes kemampuan berpikir kritis matematis sebanyak 6 butir soal dan skala kepercayaan diri siswa sebanyak 33 skala pernyataan. Data hasil penelitian diolah dan dianalisis menggunakan uji statistika regresi. Namun sebelum dilakukan uji statistika regresi, dilakukan terlebih dahulu pengujian normalitas data dan uji linearitas.

Adapun contoh instrumen tes dan non-tes secara berurutan disajikan pada Gambar 1 dan 2 berikut ini.

1. Dalam segitiga sembarang $\mathrm{ABC}$ berlaku $\sin \mathrm{A}+\sin (\mathrm{B}+\mathrm{C})=2 \sin \mathrm{A}$. bagaimana langkah-langkah pembuktiannya ? sertakan alasan tiap langkah penyelesaian.

2. Pada interval $0<x<2 \pi$, susun tiga persamaan fungsi sinus yang berbeda.

a. Di antara ketiga fungsi tersebut, manakah grafik fungsi yang memiliki nilai maksimum paling besar. Berikan alasan yang mendasari jawaban.

b. Di antara ketiga fungsi tersebut manakah grafik fungsi yang memiliki gelombang paling banyak. Sertakan alasannya.

c. 
Symmetry | Pasundan Journal of Research in Mathematics Learning and Education Volume 2 Nomor 2, Desember 2017 ISSN 2548-2297

Gambar 1. Instrumen tes tentang kemampuan berpikir kritis matematis siswa

\begin{tabular}{|c|c|c|c|c|c|}
\hline \multicolumn{6}{|c|}{ SKALA KEPERCAYAAN DIRI SISWA } \\
\hline $\begin{array}{l}\text { Keterangan: } \\
\text { SS : Sangat Sering }\end{array}$ & $\begin{array}{l}\text { angan: } \\
\text { angat Sering }\end{array}$ & \multicolumn{4}{|c|}{ JS : Jarang Sekali } \\
\hline \multirow{2}{*}{ No } & \multirow{2}{*}{ Indikator dan Kepercayaan } & \multicolumn{4}{|c|}{ Respon } \\
\hline & & SS & $\mathbf{S}$ & JR & JS \\
\hline A. & Indikator: Percaya pada kemampuan sendiri & & & & \\
\hline 1. & $\begin{array}{l}\text { Gugup ketika harus menyelesaikan soal matematika di } \\
\text { depan kelas. }\end{array}$ & & & & \\
\hline 2. & $\begin{array}{l}\text { Malu ketika harus mengerjakan soal matematika di depan } \\
\text { kelas. }\end{array}$ & & & & \\
\hline 3. & $\begin{array}{l}\text { Mampu menjelaskan kembali materi yang telah } \\
\text { disampaikan oleh guru }\end{array}$ & & & & \\
\hline 4. & $\begin{array}{l}\text { Merasa gugup ketika guru menanyakan materi pelajaran } \\
\text { yang kurang dipahami. }\end{array}$ & & & & \\
\hline
\end{tabular}

Gambar 2. Instrumen non tes tentang kepercayaan diri siswa

\section{HASIL DAN PEMBAHASAN}

Berdasarkan hasil analisis data, diperoleh bahwa kedua variabel yaitu kemampuan berpikir kritis matematis dan kepercayaan diri siswa berdistribusi normal. Selanjutnya dilakukan uji linearitas kemampuan berpikir kritis matematis atas kepercayaan diri siswa dengan hasil pengujian disajikan pada Tabel 1 berikut.

Tabel 1

Uji Linearitas antara Kepercayaan Diri dan Kemampuan Berpikir Kritis Siswa

\begin{tabular}{|c|c|c|c|c|c|c|c|}
\hline & & & $\begin{array}{c}\text { Sum of } \\
\text { Squares }\end{array}$ & df & $\begin{array}{l}\text { Mean } \\
\text { Square }\end{array}$ & $\mathbf{F}$ & Sig. \\
\hline \multirow{5}{*}{$\begin{array}{l}\text { Kemampuan } \\
\text { Berpikir Kritis } \\
\text { * Kepercayaan Diri }\end{array}$} & \multirow{3}{*}{$\begin{array}{l}\text { Between } \\
\text { Groups }\end{array}$} & (Combined) & 81,774 & 16 & 5,111 & 11,886 & 0,000 \\
\hline & & Linearity & 64,400 & 1 & 64,400 & 149,768 & 0,000 \\
\hline & & Deviation from Linearity & 17,374 & 15 & 1,158 & 2,694 & 0,059 \\
\hline & \multicolumn{2}{|c|}{ Within Groups } & 4,300 & 10 & 0,430 & & \\
\hline & \multicolumn{2}{|l|}{ Total } & 86,074 & 26 & & & \\
\hline
\end{tabular}

Berdasarkan hasil uji linearitas antara kepercayaan diri dan kemampuan berpikir kritis matematis mahasiswa, terlihat bahwa terdapat hubungan yang linear. Hal ini dikarenakan nilai Sig. dari Deviation from Linearity menghasilkan nilai 0,059, ( Sig.> $\alpha=5$ $\%)$. Selain itu tingkat linearitas antara kepercayaan diri dan kemampuan berpikir kritis tergolong kuat (Sig. $=0,000)$. 
Selanjutnya dilakukan uji statistika regresi untuk melihat apakah terdapat pengaruh dari kepercayaan diri siswa terhadap kemampuan berpikir kritis matematis dengan hasil pengujian disajikan pada Tabel 2 dan Tabel 3 berikut.

Tabel 2

Uji Regresi antara Kepercayaan Diri dan Kemampuan Berpikir Kritis Siswa

\begin{tabular}{llrrrrr}
\hline Model & & Sum of Squares & df & Mean Square & F & Sig. \\
\hline 1 & Regression & 63,656 & 1 & 63,656 & 70,310 & $0,000^{\mathrm{a}}$ \\
& Residual & 21,729 & 24 & 0,905 & & \\
& Total & 85,385 & 25 & & & \\
\hline
\end{tabular}

a. Predictors: (Constant), Kepercayaan diri

b. Dependent Variable: Berpikir Kritis

Berdasarkan pengujian regresi pada Tabel 2, didapat nilai Sig. sebesar 0,000 yang mengakibatkan bahwa kepercayaan diri siswa secara signifikan memberikan pengaruh yang positif terhadap kemampuan berpikir kritis matematis siswa pada taraf signifikansi 5\%. Selain itu besarnya koefisien korelasi adalah 0,863 dan nilai koefisien determinasi sebesar 0,746. Hal ini dapat diartikan bahwa kemampuan berpikir kritis matematis siswa dipengaruhi oleh kepercayaan diri siswa sebesar 74,6\% sedangkan 25,4\% dipengaruhi oleh faktor lain di luar kepercayaan diri siswa.

Tabel 3

Model Summary

\begin{tabular}{llccc}
\hline Model & R & R Square & Adjusted R Square & $\begin{array}{c}\text { Std. Error of } \\
\text { the Estimate }\end{array}$ \\
\hline 1 & $0,863^{\mathrm{a}}$ & 0,746 & 0,735 & 0,952 \\
\hline
\end{tabular}

a. Predictors: (Constant), Kepercayaan diri

Adapun persamaan regresi dari hasil pengujian tentang pengaruh kepercayaan diri terhadap kemampuan berpikir kritis matematis siswa adalah sebagai berikut:

$$
Y=-7,702+0,183 x
$$

Hal ini dapat diinterpretasikan bahwa apabila kepercayaan diri siswa bernilai 0 (nol), maka kemampuan berpikir kritis matematis siswa bernilai -7,702. Selain itu terlihat pula bahwa koefisien dari kepercayaan diri siswa bernilai positif artinya terdapat pengaruh yang positif antara kepercayaan diri terhadap kemampuan berpikir kritis matematis siswa. Sehingga dapat disimpulkan bahwa semakin tinggi kepercayaan diri yang dimiliki siswa, maka akan semakin tinggi pula kemampuan berpikir kritis matematis siswa tersebut.

\section{PEMBAHASAN}

Dari hasil analisis data hasil penelitian terlihat bahwa terdapat pengaruh yang positif antara kepercayaan diri terhadap kemampuan berpikir kritis matematis siswa, penyebab 
terjadinya pengaruh positif tersebut diantaranya: (1) siswa yang memiliki sikap kepercayaan diri dalam matematika cenderung lebih berani dalam mengambil langkah penyelesaian soal, di luar prosedur pada umumnya. (2) siswa yang memiliki kepercayaan diri dalam matematika cenderung memiliki ide yang banyak dalam penyelesaian soal atau memiliki lebih dari satu cara dalam menyelesaikan soal. Selain itu, untuk siswa dengan sikap kepercayaan diri yang kurang dalam matematika akan cenderung mengerjakan penyelesaian soal sesuai dengan prosedur dan lebih mengandalkan hapalan, sehingga siswa tersebut menjadi lemah dalam pengambilan keputusan saat proses penyelesaian masalah yang dialaminya (Hendriana, 2012; Rahmi, Nadia, Hasibah, \& Hidayat, 2017).

Hasil pekerjaan siswa dengan sikap kepercayaan diri dalam matematika disajikan pada Gambar 3 dan Gambar 4 berikut.

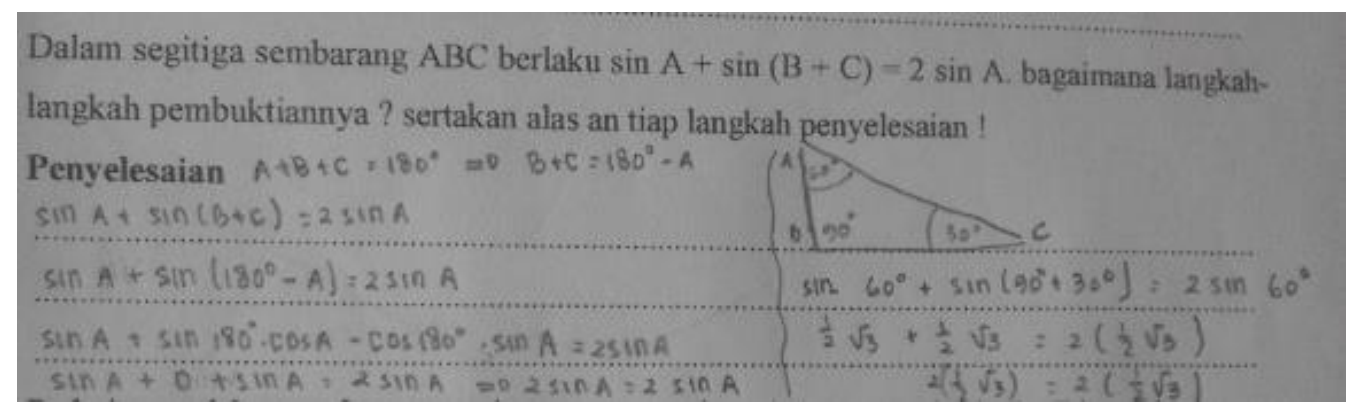

Gambar 3. Hasil pekerjaan siswa dengan sikap kepercayaan diri yang baik

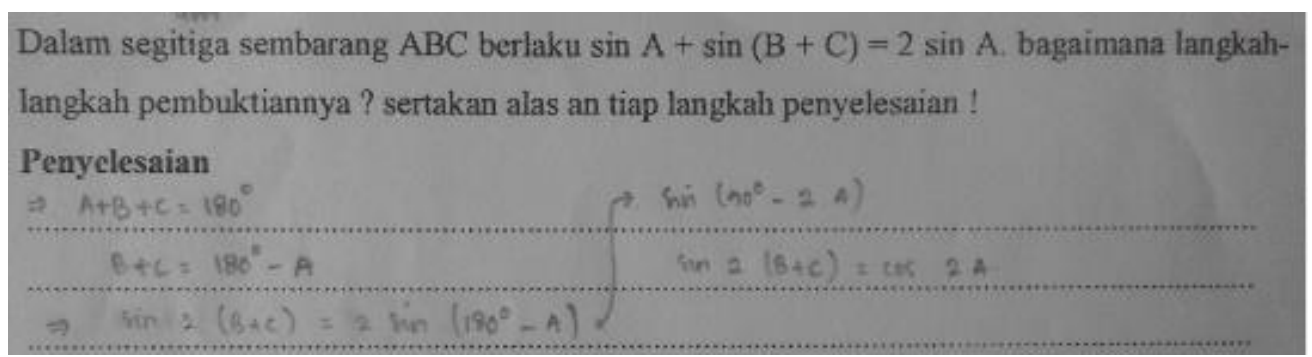

Gambar 4. Hasil pekerjaan siswa dengan sikap kepercayaan diri yang kurang baik

Pada gambar 3 terlihat hasil pekerjaan siswa yang melakukan langkah pembuktian langsung. Hal ini siswa mencari penyelesaian dari permasalahan "sin A $+\sin (B+C)$ " untuk menghasilkan solusi penyelesaian yang sama dengan persamaan yang diberikan (yaitu: $2 \sin A$ ). Selain itu, ide awal dan strategi penyelesaian yang diambil oleh siswa tersebut sudah dianggap tepat, walaupun pada akhirnya siswa tersebut melakukan pemeriksaan kembali dari hasil penyelesaian yang dia berikan. Hal ini sejalan dengan penelitian Kusdinar, Sukestiyarno, Isnarto, \& Istiandaru (2017) yang berpendapat bahwa dalam proses membuktikan suatu permasalahan, diperlukan kemampuan siswa mulai dari merumuskan ide awal dan menyusun strategi penyelesaian.

Berkaitan dengan jawaban siswa yang memiliki sikap kepercayaan diri dengan kategori kurang baik (Gambar 4) terlihat bahwa siswa tersebut memaksakan jawaban tanpa memikirkan ide awal penyelesaiannya terlebih dahulu. Sehingga ia merasa kesulitan dan pada akhirnya siswa tersebut menyerah begitu saja dengan jawaban yang tidak terselesaikan dari permasalahan yang 
Symmetry | Pasundan Journal of Research in Mathematics Learning and Education Volume 2 Nomor 2, Desember 2017 ISSN 2548-2297

diberikan. Dengan kata lain siswa tersebut sudah menyerah dalam menyelesaikan permasalahan yang diakibatkan daya juang dalam menghadapi masalah yang sangat lemah. Hal ini dikarenakan bahwa siswa yang memiliki sikap dengan daya juang yang lemah dalam menghadapi masalah akan mengakibatkan hasil yang tidak optimal, sehingga pada akhirnya tidak dapat menyelesaikan permasalahan yang sedang dihadapi (Hidayat, 2017; MZ, Risnawati, Kurniati, \& Prahmana, 2017; Oliveros, 2014; Parvathy \& Praseeda, 2014; Phoolka \& Kaur, 2012).

Berkaitan dengan hasil penelitian yang menunjukkan bahwa kemampuan berpikir kritis matematis dipengaruhi oleh kepercayaan diri siswa, dikarenakan siswa yang memiliki tingkat kepercayaan diri tinggi dapat membentuk keyakinan pada dirinya tentang kemampuan untuk pantang menyerah dalam menghadapi permasalahan yang diberikan (Hidayat, 2017; Leonard \& Amanah, 2014). Selain itu keterkaitan antara kemampuan matematika dan sikap seseorang dalam menghadapi masalah juga dipengaruhi oleh faktor pembelajaran yang menuntut peserta didik menjadi aktif dalam berpikir dan berinteraksi, sehingga dapat meningkatkan kemampuan matematika yang menjadi harapan tujuan pembelajaran pada umumnya (Hendriana, Rohaeti, \& Hidayat, 2016; Rahmi et al., 2017).

\section{KESIMPULAN}

Berdasarkan hasil dan pembahasan yang telah disajikan, maka dapat disimpulkan bahwa kemampuan berpikir kritis matematis siswa SMA dipengaruhi positif oleh kepercayaan dirinya sebesar 74,6\%, sedangkan 25,4\% dipengaruhi oleh faktor selain kepercayaan diri siswa.

\section{DAFTAR PUSTAKA}

Fatmawati, H., Mardiyana, \& Triyanto. (2014). Analisis Berpikir Kritis Siswa dalam Pemecahan Masalah Matematika Berdasarkan Polya pada Pokok Bahasan Persamaan Kuadrat (Penelitian pada Siswa kelas X SMK Muhammadiyah 1 Sragen Tahun Pelajaran 2013/2014). Jurnal Elektronik Pembelajaran Matematika, 2(9), 899-910.

Hendriana, H. (2012). Pembelajaran Matematika Humanis dengan Metaphorical Thinking untuk Meningkatkan Kepercayaan Diri Siswa. Infinity Journal, 1(1), 90-103.

Hendriana, H. (2014). Membangun kepercayaan diri siswa melalui pembelajaran matematika humanis. Jurnal Pengajaran MIPA, 19(1), 52-60.

Hendriana, H., Rohaeti, E. E., \& Hidayat, W. (2016). Metaphorical Thinking Learning and Junior High School Teachers' Mathematical Questioning Ability. Journal on Mathematics Education, 8(1), 55-64.

Hidayat, W. (2017). Adversity Quotient dan Penalaran Kreatif Matematis Siswa SMA dalam Pembelajaran Argument Driven Inquiry pada Materi Turunan Fungsi. KALAMATIKA Jurnal Pendidikan Matematika, 2(1), 15-28.

Kusdinar, U., Sukestiyarno, S., Isnarto, I., \& Istiandaru, A. (2017). Krulik and Rudnik Model Heuristic Strategy in Mathematics Problem Solving. International Journal on Emerging Mathematics Education, 1(2), 205-210.

Leonard, L., \& Amanah, N. (2014). Pengaruh Adversity Quotient dan Kemampuan Berpikir Kritis Terhadap Prestasi Belajar Matematika. Jurnal Perspektif Ilmu Pendidikan, 28(1), $55-64$.

MZ, Z. A., Risnawati, R., Kurniati, A., \& Prahmana, R. C. I. (2017). Adversity Quotient in Mathematics Learning (Quantitative Study on Students Boarding School in Pekanbaru). 
International Journal on Emerging Mathematics Education, 1(2), 169-176.

Noordyana, M. A. (2016). Meningkatkan Kemampuan Berpikir Kritis Matematis Siswa melalui Pendekatan Metacognitive Instruction. Mosharafa Vol. 5, No. 2, Mei 2016, 5(2), 120 127.

Oliveros, J. C. (2014). Adversity Quotient and Problem-solving Skills in Advanced Algebra. JPAIR Multidisciplinary Research, 17(1). https://doi.org/10.7719/jpair.v17i1.282

Parvathy, U., \& Praseeda, M. (2014). Relationship between Adversity Quotient and academic problem among student teachers. Journal of Humanities and Social Science, 19(11), 2326.

Phoolka, E. S., \& Kaur, N. (2012). Adversity Quotient: A new paradigm to explore. Contemporary Business Studies, 3(4), 67-78.

Rahmi, S., Nadia, R., Hasibah, B., \& Hidayat, W. (2017). The Relation between Self-Efficacy toward Math with the Math Communication Competence. Infinity Journal, 6(2), 177182.

Rohaeti, E. E. (2010). Critical and creative mathematical thinking of Junior High School student. Educationist Journal, 4(2), 99-106.

Rosita, N. T. (2017). Implementasi Pembelajaran Matematika dengan Pendekatan Open Ended terhadap Sikap Siswa. Symmetry: Pasundan Journal of Research in Mathematics Learning and Education, 1(1), 1-12.

Sumarmo, U., Hidayat, W., Zukarnaen, R., Hamidah, M., \& Sariningsih, R. (2012). Kemampuan dan Disposisi Berpikir Logis, Kritis, dan Kreatif Matematik (Eksperimen terhadap Siswa SMA Menggunakan Pembelajaran Berbasis Masalah dan Strategi Think-Talk-Write). Jurnal Pengajaran MIPA, 17(1), 17-33. 